\title{
Terminal 22q deletion associated with a partial deficiency of arylsulphatase A
}

\author{
K Narahara, Y Takahashi, M Murakami, K Tsuji, Y Yokoyama, R Murakami, \\ S Ninomiya, Y Seino
}

\begin{abstract}
A 7 month old girl with psychomotor retardation, hypotonia, and minor malformations was found to have a terminal deletion of the long arm of chromosome 22, del(22)(q13.31). The partial deficiency of arylsulphatase $A$ (ARSA) and the normal level of NADH diaphorase 1 (DIA1) suggests that the ARSA locus can be regionally assigned to $22 \mathrm{q} 13.31 \rightarrow$ qter and the DIA1 locus can be excluded from the same segment. This report is the third published case with a terminal $22 \mathrm{q}$ deletion.
\end{abstract}

Partial monosomy 22 has been reported in relatively few cases. Most of them have an $r(22)$, and there have been only two instances of a terminal deletion of the long arm. ${ }^{12} \mathrm{We}$ describe here another patient with a terminal 22q deletion. Gene dosage studies of arylsulphatase A (ARSA) and diaphorase 1 (DIA1) supported their localisations on the distal long arm of chromosome 22.

\section{Case report}

A female patient was seen when she was 7 months old. She was the third child of 26 year old parents. There was no family history of miscarriage or multiple congenital anomalies. Her parents and two older sibs were healthy. The pregnancy and delivery were uneventful. Birth weight was $3020 \mathrm{~g}$ (50th centile), length $50.5 \mathrm{~cm}$ (50th centile), and head circumference (OFC) $33.0 \mathrm{~cm}$ (30th centile). At the age of 2 months, the infant was admitted to hospital because of failure to thrive, congenital stridor, and hypotonia. Laboratory studies, including urine analysis, complete blood counts, serum creatine kinase, blood lactate and amino acid levels, electroencephalography, electromyography, and cranial CT scan, showed normal results. An indwelling nasogastric tube was placed because of poor feeding. At 3 and 6 months of age, respectively, the infant was admitted to hospital because of bacterial pneumonia. Physical examination at the age of 7 months showed a floppy infant with a few minor malformations (fig 1). The patient weighed $6800 \mathrm{~g}$ (10th centile), was $70.5 \mathrm{~cm}$ long (50th centile), and had an OFC of $43.0 \mathrm{~cm}$ (30th centile). The head was plagiocephalic with a flat left occiput. The eyes were almond shaped and deeply set and the palpebral fissures slanted slightly upwards. The ears were rather large. There were also full eyebrows, micrognathia, high arched palate, and subcutaneous syndactyly between the second and third toes.

The subsequent clinical course was marked by profound psychomotor retardation and several episodes of lower respiratory tract infections. At 2 years of age, the patient's developmental quotient was $25 \%$ that of a child of the same age. The patient's weight was $9205 \mathrm{~g}$ (3rd centile), height was $85.0 \mathrm{~cm}$ (50th centile), and her OFC was $46.3 \mathrm{~cm}$ (30th centile). She died suddenly at $2 \frac{1}{2}$ years of age. Permission for necropsy was not granted.

High resolution GTG banding analysis of cultured lymphocytes and skin fibroblasts showed a terminal deletion of the long arm of chromosome 22 in all cells examined (fig 2). Her karyotype was designated $46, \mathrm{XX}, \operatorname{del}(22)(\mathrm{pter} \rightarrow \mathrm{q} 13.31:)$. The parents had normal chromosomes. Unfortunately, a cell line is not available from this patient.

$\mathrm{NADH}$ diaphorase activity of red blood cells (DIA1) was measured using the method of Hegesh et $a l,{ }^{3}$ and arylsulphatase A (ARSA) activity in leucocytes was assayed using the method of Galjaard. ${ }^{4}$ The DIA1 level was normal $(2.59 \mu \mathrm{mol} / \mathrm{min} / \mathrm{g} \mathrm{Hb}, 104 \%$ of the normal value), while the ARSA activity was reduced $(51 \mathrm{nmol} / \mathrm{h} / \mathrm{mg}$ protein, $52 \%$ of the normal and $42 \%$ of the mean parental value).

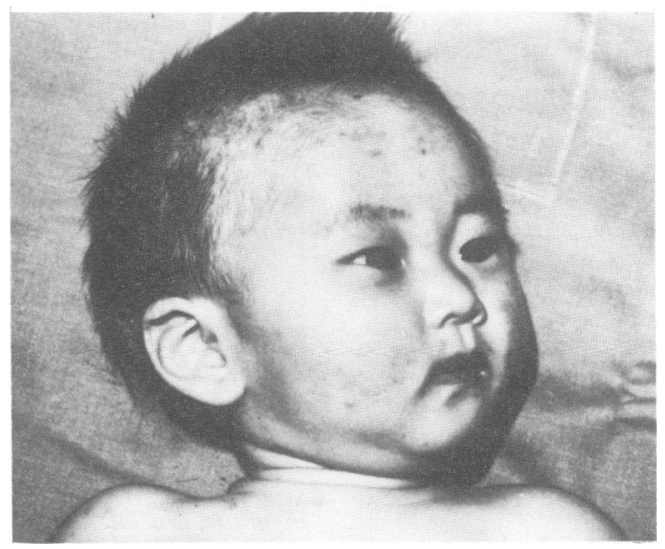

Figure 1 The proband aged 7 months 


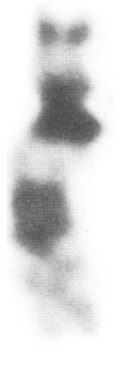

22

$\operatorname{del}(22)$

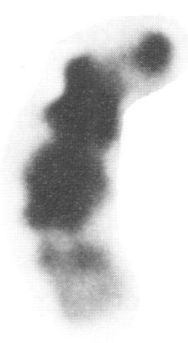

22

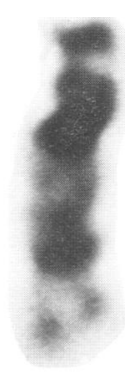

$\operatorname{del}(22)$
Figure 2 Partial karyotype of the proband

The results are compatible with hemizygous deficiency of the ARSA locus in the patient.

\section{Discussion}

This is the third published case of a patient with a terminal deletion of the long arm of chromosome 22. The first patient had both monosomy for $22 \mathrm{q} 12 \rightarrow \mathrm{qter}$ and trisomy for $22 \mathrm{pl} 1 \rightarrow$ pter, resulting from a recombination of a maternal pericentric inversion of chromosome 22 , inv(22)(p11q12). ${ }^{1}$ In this patient, however, the breakpoint on the long arm of chromosome 22 is more likely to be in $22 \mathrm{q} 13$. The second patient had de novo monosomy for $22 \mathrm{q} 13.31 \rightarrow$ qter. $^{2}$ This patient was ascertained because of multiple congenital anomalies, mental retardation, and, interestingly, the Goldenhar complex.

Clinical findings in the reported cases with a terminal deletion of $22 q$ and those with $r(22)$.

\begin{tabular}{|c|c|c|c|c|}
\hline & $\begin{array}{l}\text { Watt } \\
\text { et } a l^{1}\end{array}$ & $\begin{array}{c}\text { Herman } \\
\text { et } a l^{2}\end{array}$ & Present case & $\begin{array}{c}\text { Cases with } \\
\mathrm{r}(22)^{5} \\
(\%)\end{array}$ \\
\hline $\begin{array}{l}\text { Age at examination } \\
\text { Sex }\end{array}$ & $14 \mathrm{y}$ & Newborn & $7 \mathrm{mth}$ & $16 \mathrm{M} / 18 \mathrm{~F}$ \\
\hline Birth weight (g) & ND & 3105 & 3020 & 2960 \\
\hline Developmental delay & + & + & + & 90 \\
\hline Poor weight gain & ND & ND & + & 29 \\
\hline Short stature & + & ND & - & 17 \\
\hline Hypotonia & - & ND & + & 75 \\
\hline Unsteady gait & + & 1 & 1 & 87 \\
\hline EEG abnormality & - & + & - & 50 \\
\hline Microcephaly & - & Macro & - & 41 \\
\hline Epicanthic folds & + & - & - & 86 \\
\hline Full eyebrows & + & - & + & 100 \\
\hline Deep set eyes & + & - & + & \\
\hline Large ears & + & - & + & 73 \\
\hline Abnormal ears & + & + & - & 85 \\
\hline Micrognathia & - & - & + & 28 \\
\hline High arched palate & - & + & + & 42 \\
\hline Dental malocclusion & + & 1 & 1 & 54 \\
\hline Thick lips & - & - & - & 77 \\
\hline Syndactyly of toes & + & - & + & 60 \\
\hline Clinodactyly & + & - & - & 32 \\
\hline
\end{tabular}

The table summarises the clinical findings in these three patients together with findings for patients with a ring chromosome 22 for phenotypic comparison. In the patients with terminal 22q deletions, mental retardation was the only common finding. In the patients with $r(22)$ who also had monosomy for distal 22q, there were no consistent features except for non-specific abnormalities such as mental retardation, hypotonia, epicanthic folds, full eyebrows, ear malformations, thick lips, and syndactyly. ${ }^{5}$ While deletions of proximal 22q are associated with the DiGeorge syndrome, ${ }^{6}$ deletions of distal 22q may not produce any distinctive phenotype.

Both the ARSA and DIA1 loci have been assigned to $22 \mathrm{q} 13.31 \rightarrow$ qter $\left(\right.$ HGM10). ${ }^{7}$ The results of gene dosage studies in our patient indicate that the ARSA locus can be mapped regionally to $22 \mathrm{q} 13.31 \rightarrow$ qter, and that the shortest overlapping region with the DIA1 locus can be narrowed to 22q13.31. Partial deficiency of ARSA is known to be associated with metachromatic leucodystrophy. The existence of a patient with a deleted $r(22)$ who later had progressive polyneuropathy ${ }^{8}$ emphasises the importance of an ARSA assay in the clinical evaluation of patients with distal 22q monosomy.

Another prominent finding in the present patient is marked axial hypotonia, a feature also characteristic of the patients with $r(22)$. The myoglobin locus $(M B)$ has been mapped to the long arm of chromosome 22, $22 \mathrm{q} 11.2 \rightarrow \mathrm{q} 13$ (HGM10). ${ }^{7}$ It remains to be determined whether the marked hypotonia is the result of a hemizygous deficiency of the $\mathrm{MB}$ locus or of some locus crucial to cerebellar embryogenesis.

1 Watt JL, Olson IA, Johnston AW, Ross HS, Couzin DA, Stephen GS. A familial pericentric inversion of chromosome 22 with a recombinant subject illustrating a 'pure' partial monosomy syndrome. $\mathcal{F}$ Med Genet 1985;22:283-7.

Herman GE, Greenberg F, Ledbetter DH. Multiple congenital anomaly/mental retardation (MCA/MR) syndrome with Goldenhar complex due to a terminal del(22q). Am J Med Genet 1988;29:909-15.

3 Hegesh E, Calmanovici N, Avron M. New method for determining ferrihemoglobn reductase (NADH methemoglobin reductase) in erythrocytes. $\mathcal{f}$ Lab Clin Med 1968;72:339-44.

4 Galjaard H. Genetic metabolic disease. Amsterdam: Elsevier/North-Holland, 1982.

5 Naritomi K, Hirayama $K$. Determination of the breakpoints and the parental origin of a ring 22 chromosome: an analysis by high-resolution banding techniques, quinacrine and silver stainings. Fpn $\mathcal{F}$ Hum Genet 1988;33:67-73.

6 Greenberg F, Elder FFB, Haffner P, Northrup H, Ledbetter DH. Cytogenetic findings in a prospective series of patients with DiGeorge anomaly. Am $\mathcal{f}$ Hum Genet 1988;43:605-11.

7 Kaplan JC, Emanuel BS. Reports of the committee on the genetic constitution of chromosome 22. Cytogenet Cell Genet $1989 ; 51: 372-83$.

8 Gustavson KH, Arancibia W, Eriksson U, Svennerholm L. Deleted ring chromosome 22 in a mentally retarded boy. Clin Genet 1986;29:337-41. 